Bulletin of the Natural History Museum, 2016, 9: 67-79.

Received 23 Aug 2016; Accepted 27 Nov 2016.

doi:10.5937/hnhmb1609067T

UDC: $582.842 .2(497.11)$

Original scientific paper

\title{
VIOLA ORBELICA (VIOLACEAE), NEW SPECIES FOR THE FLORA OF SERBIA
}

\author{
GORDANA TOMOVIĆ ${ }^{1}$, BOJAN ZLATKOVIĆ ${ }^{2}$, MAJA LAZAREVIĆ ${ }^{1}$ \\ MARJAN NIKETIĆ \\ ${ }^{1}$ Institute of Botany and Botanical Garden, Faculty of Biology, University of \\ Belgrade, 11000 Belgrade, Serbia, \\ e-mail: gtomovic@bio.bg.ac.rs; majat@bio.bg.ac.rs \\ ${ }^{2}$ Department of Biology and Ecology, Faculty of Sciences and Mathematics, \\ University of Niš, Višegradska 33, 18000 Niš, Serbia, \\ e-mail: bojanzlat@pmf.ni.ac.rs \\ ${ }_{3}^{3}$ Natural History Museum, 11000 Belgrade, Serbia, e-mail: mniketic@nhmbeo.rs
}

During two botanical expeditions in southeast Serbia (Mt. Dukat) one intriguing species of the genus Viola ( $V$. sect. Melanium) was found. Intensive inspection and comparation with the plant material from several herbarium collections revealed that it is $V$. orbelica Pančić, which is a new species for the flora of Serbia. Morphological description, general distribution, ecological traits, chromosome number as well as threatened status of the newly discovered Viola plant in Serbia are presented.

Key words: Viola orbelica, distribution, threatened status, Serbia

\section{INTRODUCTION}

In the last five years, several articles about genus Viola L. in Serbia and the Balkan Peninsula were published (Niketić 2014; Stevanović et al. 2014; Tomović et al. 2013; 2014; 2016). Niketić et al. (2015) pointed out that the number of Viola species in Serbia is not final, since the intensive and long- 
standing field work and inspection of the herbarium collections could result in discovering some new Viola species either for the whole Balkan Peninsula or for the territory of Serbia.

The prove of such assumption is discovery of a new species from $V$. sect. Melanium Ging. for the flora of Serbia. Namely, authors obtained first Viola specimens from Mt Dukat from herpetologist $\mathrm{Lj}$. Tomovic in June 2014. After several personal visits of authors to the locality and collection of enough plant material, detailed comparison of these specimens with other Viola taxa from Serbia and surrounding Balkan countries was conducted. This included checking and inspection of the plant material from several herbarium collections (BEO, BEOU) and only after that it was proved that these intriguing Viola specimens belong to the species Viola orbelica Pančić

\section{MATERIAL AND METHODS}

Field investigation, checking and revision of herbarium material and consulting literature sources (Delipavlov 1979; Erben 1985; Micevski 1995) were essential for identification of the new species for the flora of Serbia. Distribution of the species in the Balkan Peninsula is accomplished according to the grid map with squares of $10 \mathrm{~km} \times 10 \mathrm{~km}$, based on the Military Grid Reference System (MGRS) projection (Lampinen 2001). Collected plant material is deposited in the Herbarium of the Institute of Botany and Botanical Garden "Jevremovac", University of Belgrade (BEOU) and the Herbarium of the Natural History Museum in Belgrade (BEO) (Thiers 2013; $\mathrm{http}$ //sciweb.nybg.org/Science2/IndexHerbariorum.asp). Nomenclatureis given according to The Plant List database (http://www.theplantlist.org/) and Euro+Med (2006-) (http://ww2.bgbm.org/ EuroPlusMed/). Taxon description is given according to several botanical sources (Pančić 1883; Valentine et al. 1968; Delipavlov 1979; Erben 1985; Micevski 1995), with some modifications which are the results of the field observations.

Germinating seeds collected in the field were used for mitotic chromosome analyses. Root-tip meristems were pre-treated with $0.002 \mathrm{M} \mathrm{8-}$ hydroxyquinoline for $4 \mathrm{~h}$ at $10^{\circ} \mathrm{C}$. After fixation in cold $3 / 1(\mathrm{v} / \mathrm{v})$ ethanol/ acetic acid for 48 hours, root tips were stored in $70 \%$ ethanol at $4^{\circ} \mathrm{C}$. Hydrolysis was performed in $1 \mathrm{~N} \mathrm{HCl}$ for 11 minutes at $60^{\circ} \mathrm{C}$ and staining in Schiff reagent (Feulgen \& Rossenbeck, 1924), followed by squash in a drop of acetic carmine. Chromosome plates were observed under a Leica DMLS light microscope (Leica Microsystems, Wetzlar, Germany) and photographs were taken with a Leica DCF 295 camera (Leica Microsystems). The chromosome number was determined from at least five individuals and from at least 10 cells per root tip. 


\section{RESULTS AND DISCUSSION}

Viola orbelica Pančić, Glasn. Srpskog Učenog Društva 53: 176 (1883) [Elem. Fl. Bulg.: 16].

$\equiv V$. saxatilis [subsp. macedonica] f. orbelica (Pančić) Hayek, Repert. Spec. Nov. Regni Veg. Beih. 30(1): 517 (1925) [Prodr. Fl. Penins. Balc. $1] \equiv V$. alpestris f. orbelica (Pančić) Becker, Beih. Bot. Centralbl., Abt. 2 26(3): 345 (1910).

\section{Description}

Plant usually annual to biennial (rarely short-lived perennial) greyish white, glabrous to short pubescent. Stem (5)10-15(30) $\mathrm{cm}$ high, ascending branched from base. Lower leaves $12-30 \times 6-9 \mathrm{~mm}$ at time of flowering, usually smaller then the other ones, with longer petioles than those from middle and upper; blade ovate to orbicular, obtuse or rounded, coarsely crenate, shortly pubescent. Stipules of lower leaves small, shortly pubescent and $1 / 6-1 / 3$ as long as lower leaves, oblong to oblong-spathulate, entire or two- to three-partite. The terminal segment elongate-lanceolate, on the inner side with $0-1$ and on outer side with $1-3$ very small, narrow triangular to oblong-lanceolate lateral segments. Middle and upper leaves $22-45 \times 5-12 \mathrm{~mm}$ at time of flowering wide lanceolate to oblanceolate, sometimes at the middle of the stem ovate to obovate with shorter petioles; blade ovate-lanceolate or oblanceolate, 1.5-2 times longer than stipules, gradually attenuated at the base into the petiole, obtuse or acute, crenate, densely pubescent. Petiole $0.3-0.6$ as long as leaf blade, $0.7-1.1 \mathrm{~mm}$ wide, sparse to densely short pubescent. Stipules of middle and upper leaves 1/4$2 / 5$ shorter than the leaves, pinnately divided, pubescent; the undivided terminal part relatively large, leaf-like; there are 1-3 lateral segments on the inner and $2-6$ on the outer side of the stipules, which are tapering gradually downwards. Peduncles up to $15 \mathrm{~cm}$, puberulent to pubescent only in lower part. Bracts at a distance of $1 / 5-1 / 4$ of the length of the peduncle below the flower, $1.6-2.8 \times 0.9-1.3 \mathrm{~mm}$, narrow triangular to ovate, near the base, on either side, with 1-2 small, narrow triangular glands. Flowers small to medium size $1.3-2.0 \mathrm{~cm}$, orbicular or obovate, $1-5$ on the stem, solitary in the axils of the cauline leaves, not fragrant. Sepals 7-10 $\times 1.5-$ $2.5 \mathrm{~mm}$, elongate lanceolate, acuminate, mostly glabrous on back, longciliate at margin; margin with 1-3 \pm conspicuous short teeth on both sides, or often entire. Appendages $1 / 4$ as long as sepals, narrow to wide rectangular, trapezoid or semiorbicular, attenuate at base, coarsely dentate. Petals yellow, rarely bluish-violet or bicolor, at the base orange, upper petals 9-12 $\times 5-9 \mathrm{~mm}$, obovate to orbiculate; lateral 9-13 $\times 4.5-7.5 \mathrm{~mm}$, narrow orbiculate to obovate, lower petals (including spur) $14.5-21 \times 6-11 \mathrm{~mm}$, 


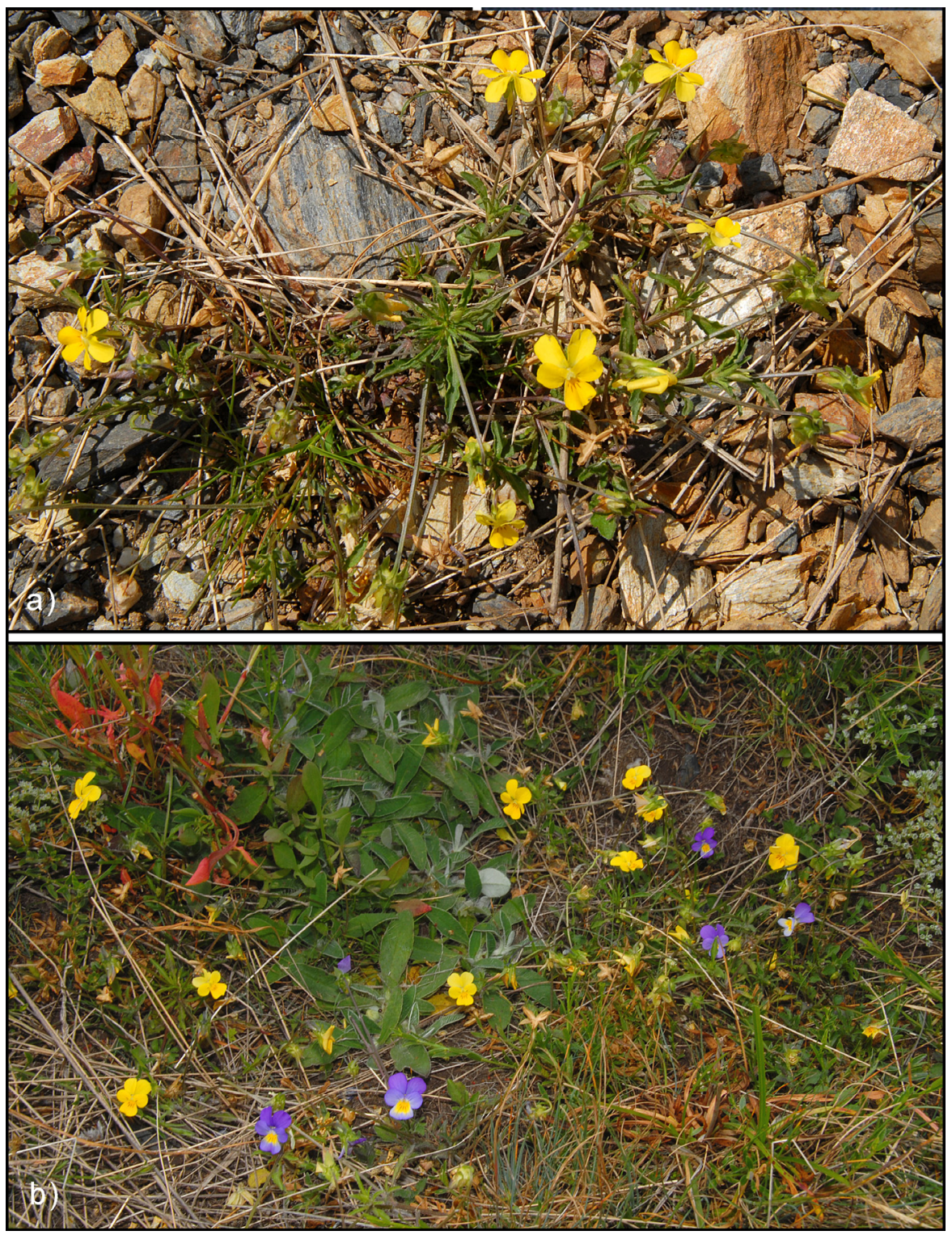

Fig. 1. - Viola orbelica Pančić - habitus: a) typical plant with yellow flowers; b) plants with yellow and bluish-violet flowers (photo M. Niketić).

cordate to almost triangular, usually longitudinally folded along the midrib. Spur glabrous, $4.8-7.5 \mathrm{~mm}$ long, reaching $3 / 10$ to $4 / 10$ of the lower petal length, elliptical in cross-section (median diameter $1.2-1.7 \mathrm{~mm}$ ), straight to slightly curved upwards, pale violet or greenish. Fruit a capsule. Seeds ellipsoid 1.7-1.8 $\times 0.9-1.0 \mathrm{~mm}$, pale to dark brown. Flowering period: JuneJuly; fructification from July to September (Figs 1-3). 

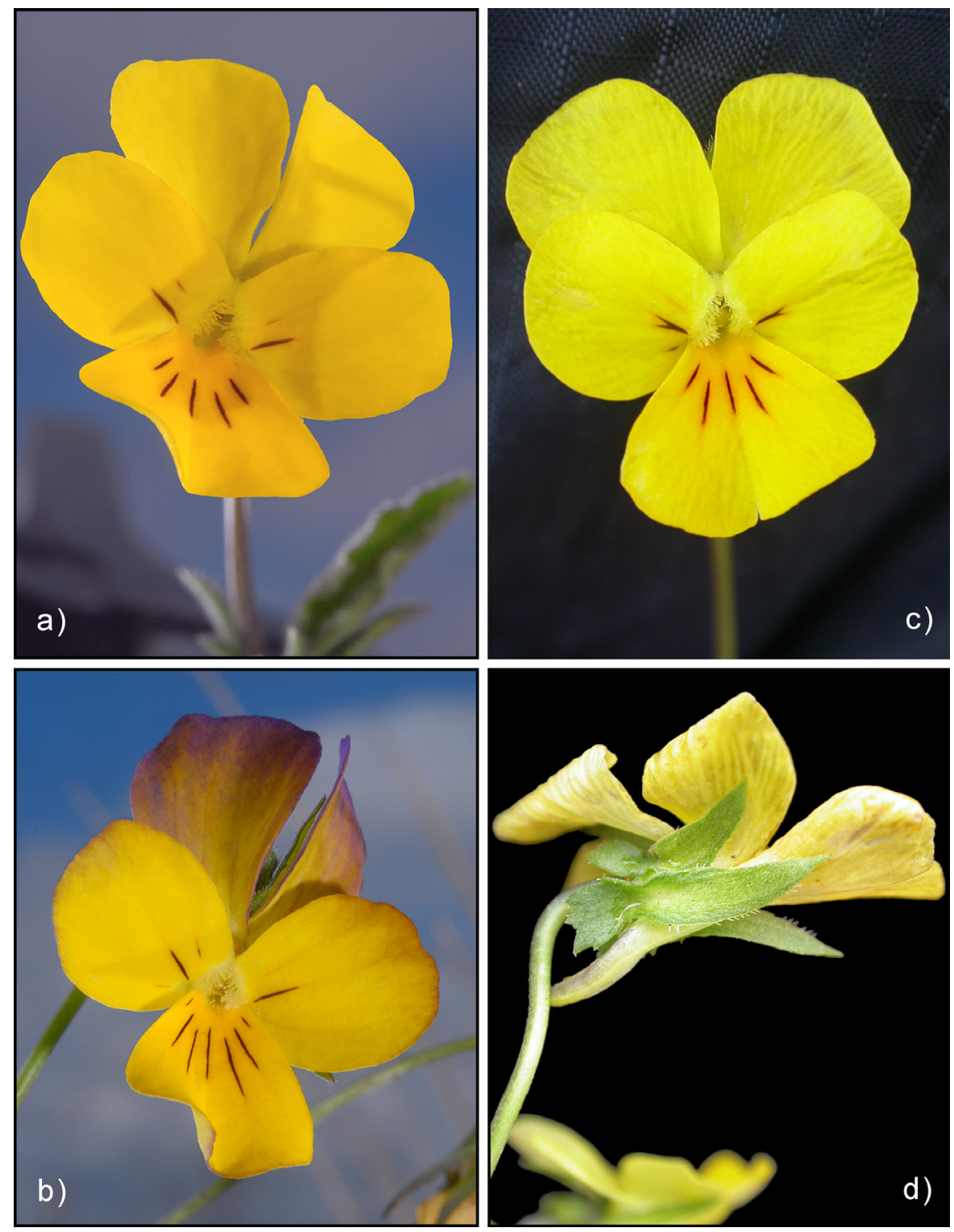

Fig. 2. - Viola orbelica Pančić - yellow flowers (photo: M. Niketić (a-b) and G. Tomović (c-d)).

Note: Only the yellow colour of the flowers was known so far, which we also noted on the type locality (Mts. Rila in Bulgaria) during field observations. However in Mt. Dukat (Serbia) as well as in Mt. Osogovski Planini (Macedonia) [MGRS 34T FM26] we also found some plants with bluishviolet and bicolor flowers (Fig. 1, 3). Both localities (in Serbia and Macedonia) are situated at the farthest western points of the species range (Fig. 4). 

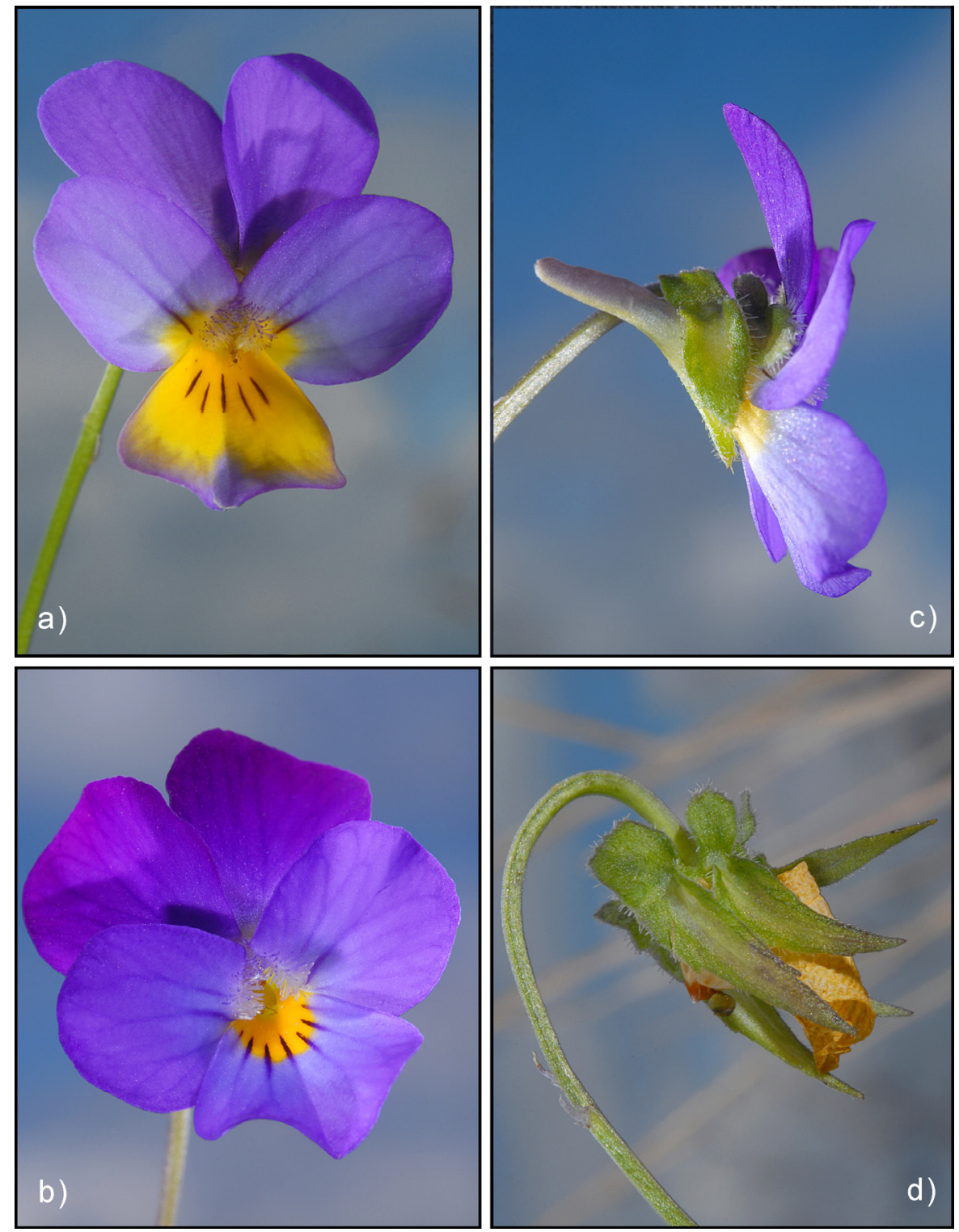

Fig. 3. - Viola orbelica Pančić - bicolor flower (a), bluish-violet flowers (b-c) and calyx after anthesis (d) (photo M. Niketić).

\section{Taxonomic membership}

$V$. orbelica Pančić belongs to $V$. sect. Melanium and it was firstly described as a species from Mts. Rila in Bulgaria (Pančić 1883). In later Viola monographic publication (Becker 1910) and Flora of the Balkan Peninsula (Hayek 1925) it was treated as form either of $V$. alpestris (DC.) 
Becker or of $V$. saxatilis subsp. macedonica (Boiss. \& Heldr.) Hayek. In the Flora Europaea it had unresolved status and been related either to $V$. gracilis Sibth. \& Sm. or to V. tricolor subsp. macedonica (Boiss. \& Heldr.) A. Schmidt (Valentine et al. 1968). However, Erben (1985) and Dimopoulos et al. (2013) considered that $V$. gracilis was erroneously cited for the Balkan Peninsula, since it is confined to Turkey (Anatolia) only.

Erben (1985) also considered $V$. orbelica as closely related to the taxa of $V$. tricolor group by many morphological features, such as their growth form, arrangement of the cauline leaves, shape and the degree of division of the stipules, relatively short, slender and upwardly curved spur, as well as the same chromosome number $(2 \mathrm{n}=26)$. On the other side, from $V . t$. subsp. macedonica it differs by narrower leaves, and even more by deeply pinnately incised (near to the middle veins) stipules; lateral lobes of the middle leaves stipule are 5- to 10- times longer than undivided part of the stipules (in $V$. $t$. subsp. macedonica 3 - to 5-times longer); terminal segment is enlarged, linear-lanceolate, much longer than the lateral lobes.

\section{General distribution}

Delipavlov (1979) and Erben (1985) considered this species endemic to Bulgaria and confined to the mountain ranges of Rila and Pirin. Interestingly, Erben (1985) erroneously published herbarium specimens of $V$. orbelica from Mt. Centralna Stara Planina ["Balkan-Gebirge: Hütte Rai am Botev, 8.1960, Lepper \& Lippold (JE)"]. Later, it was confirmed for eastern part of the Republic of Macedonia (Mt. Osogovski Planini, Mt. Golak and Mt. Plačkovica) (Micevski 1995) and only recently, it was also found in the Mts. Rhodope in NE Greece (Dimopoulos et al. 2013) (Fig. 4).

\section{Distribution in Serbia}

Southeast Serbia: Mt. Dukat: between Bandera peak and Beli Kamen peak [Karamanica], 42.36712 N; 22.31836 E, [MGRS 34T FM09], on silicate (quartz latite and schists) rocks, $1730 \mathrm{~m}, 22.06 .2014$, coll. Tomović, G., Zlatković, B., Tomović, Lj. det. M. Niketić, G. Tomović (BEOU 40775); between Bandera peak and Beli Kamen peak, [MGRS 34T FM09], on silicate (quartz latite and schists) rocks, 1610-1730 m, 29.06.2016, coll./det. M. Niketić, G. Tomović (BEO k20160604/1; BEOU 40000) (Fig. 4).

\section{Habitat and ecology}

$V$. orbelica inhabits alpine rocky pastures, predominantly on silicate at heights of (1200-)1500-2000(-2300) m a.s.l. in Bulgaria (Delipavlov 1979, Erben 1985). In the Republic of Macedonia it grows on subalpine rocks and 
rocky grounds on silicate geological substrate, at the altitude from 1000 to 2200 m a.s.l. (Micevski 1995).

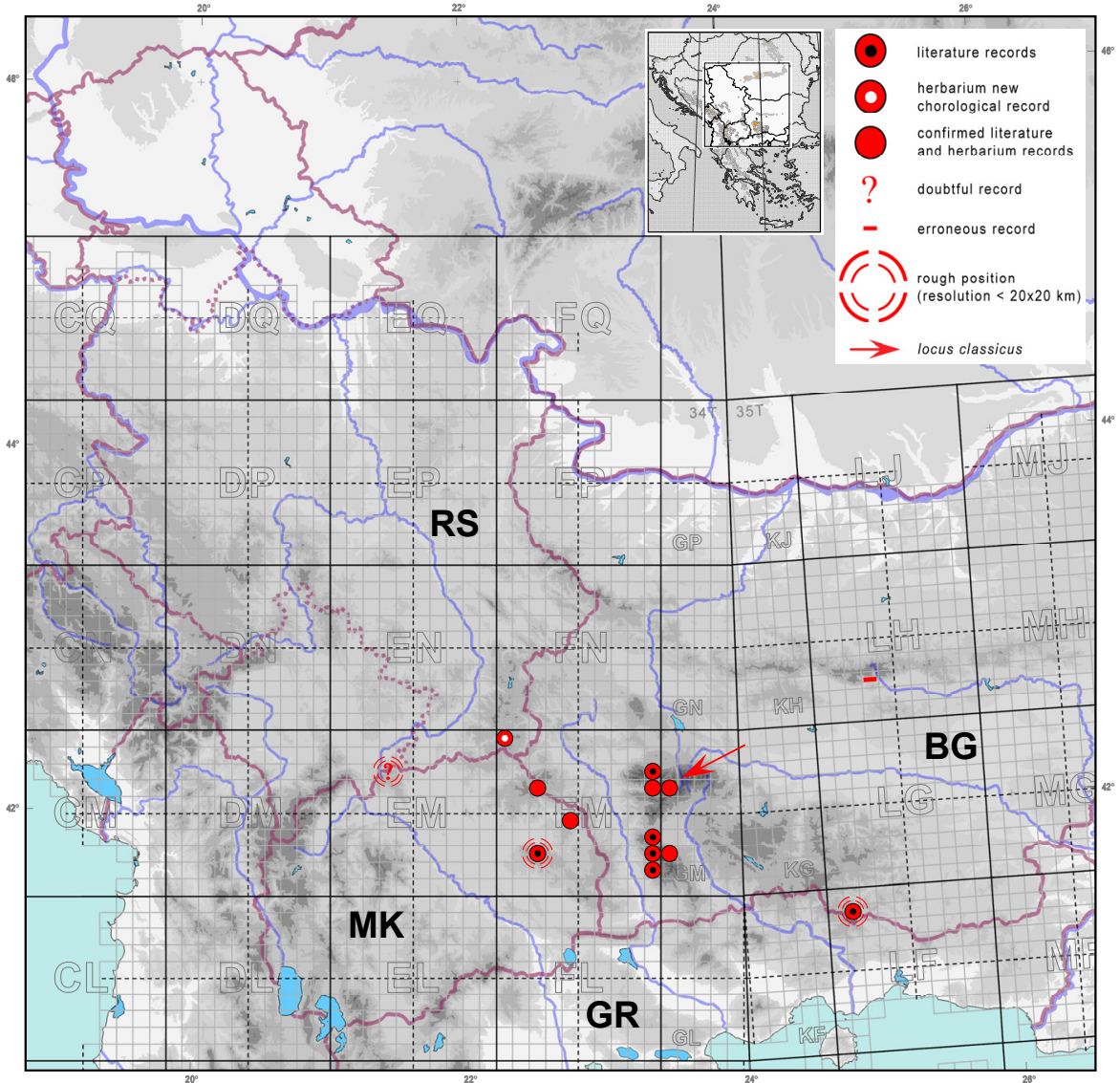

Fig. 4. Distribution of Viola orbelica Pančić in the Balkan Peninsula.

Serbian population of $V$. orbelica on Mt. Dukat was found on eroded silicate (quartz latite and schists) high-mountain pastures and rocky grounds of the vegetation class Juncetea trifidi Hadač in Klika et Hadač 1944, on the elevation between $1610 \mathrm{~m}$ and $1730 \mathrm{~m}$ a.s.l. Habitat of the species is dominated by the following plant taxa: Viola orbelica Pančić, Deschampsia flexuosa (L.) Trin., Hypericum barbatum Jacq., H. maculatum Crantz, Cytisus eriocarpus Boiss., Cerastium arvense L., Rumex acetosella L., Agrostis canina L., Thymus longicaulis C. Presl, Ornithogalum orthophyllum subsp. kochii (Parl.) Zahar., Pilosella hoppeana (Schultes) F.W. Schultz \& Schultz Bip., Genista sagittalis L., Anthoxanthum odoratum L., Festuca stricta subsp. sulcata (Hack.) Pils, Armeria rumelica Boiss., Scleranthus perennis L., Ranunculus sartorianus Boiss. \& Heldr., Minuartia bulgarica (Velen.) Graebn., Trifolium velenovskyi Vandas, Allium melanantherum Pančić, Verbascum 
longifolium Ten., Potentilla neglecta Baumg., Antennaria dioica (L.) Gaertn, Centaurea velenovskyi Adamović, Alchemilla bulgarica Rothm., A. flabellata A. Kern., A. lanuginosa Rothm. Actually, $V$. orbelica is the most frequent on the edges of the rocky grounds, near the high-mountain tracking road (Fig. 5).

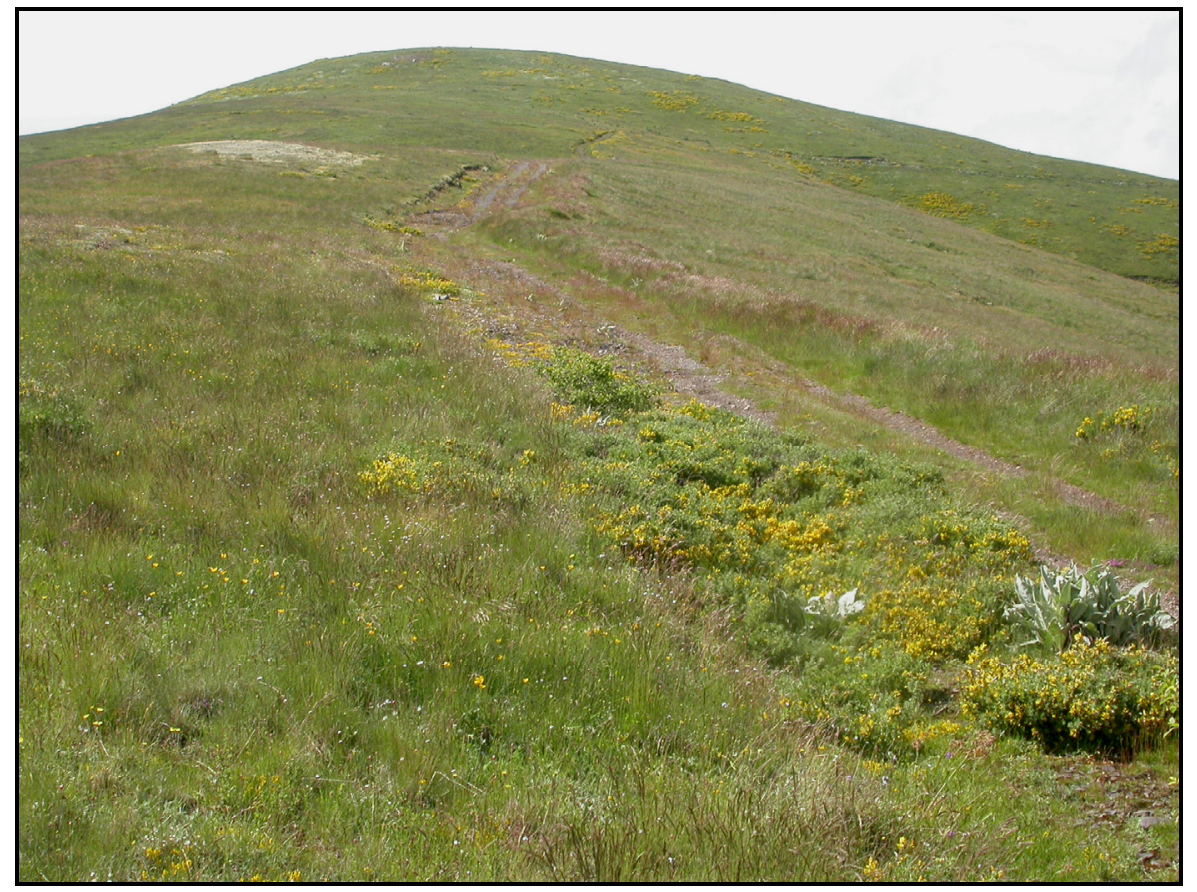

Fig. 5. - Habitat of Viola orbelica Pančić in Mt. Dukat (Beli Kamen) (photo G. Tomović).

\section{Chromosome number}

According to Valentine et al. (1968), unconfirmed chromosome number is $2 n=20$, but Erben (1985) cited Merxmüller (1974) who counted $2 n=26$. Specimens of $V$. orbelica from Mt. Dukat are diploids with $2 n=2 x=26$ chromosomes. Chromosomes are small, 0.86 to $3.37 \mu \mathrm{m}$ long (Fig. 6).

\section{Population size and area of occupancy in Serbia}

This plant occurs on restricted area of $0.15 \mathrm{~km}^{2}(1500 \times 100 \mathrm{~m})$ between Bandera and Beli Kamen peaks in Mt. Dukat, from 1610 to 1730 $\mathrm{m}$ a.s.l. Population size is estimated to be less than 1000 mature individuals. The major threat for the only population of $V$. orbelica in Serbia is habitat destruction, since the large portion of the population is restricted to the edge of the high-mountain tracking road. 


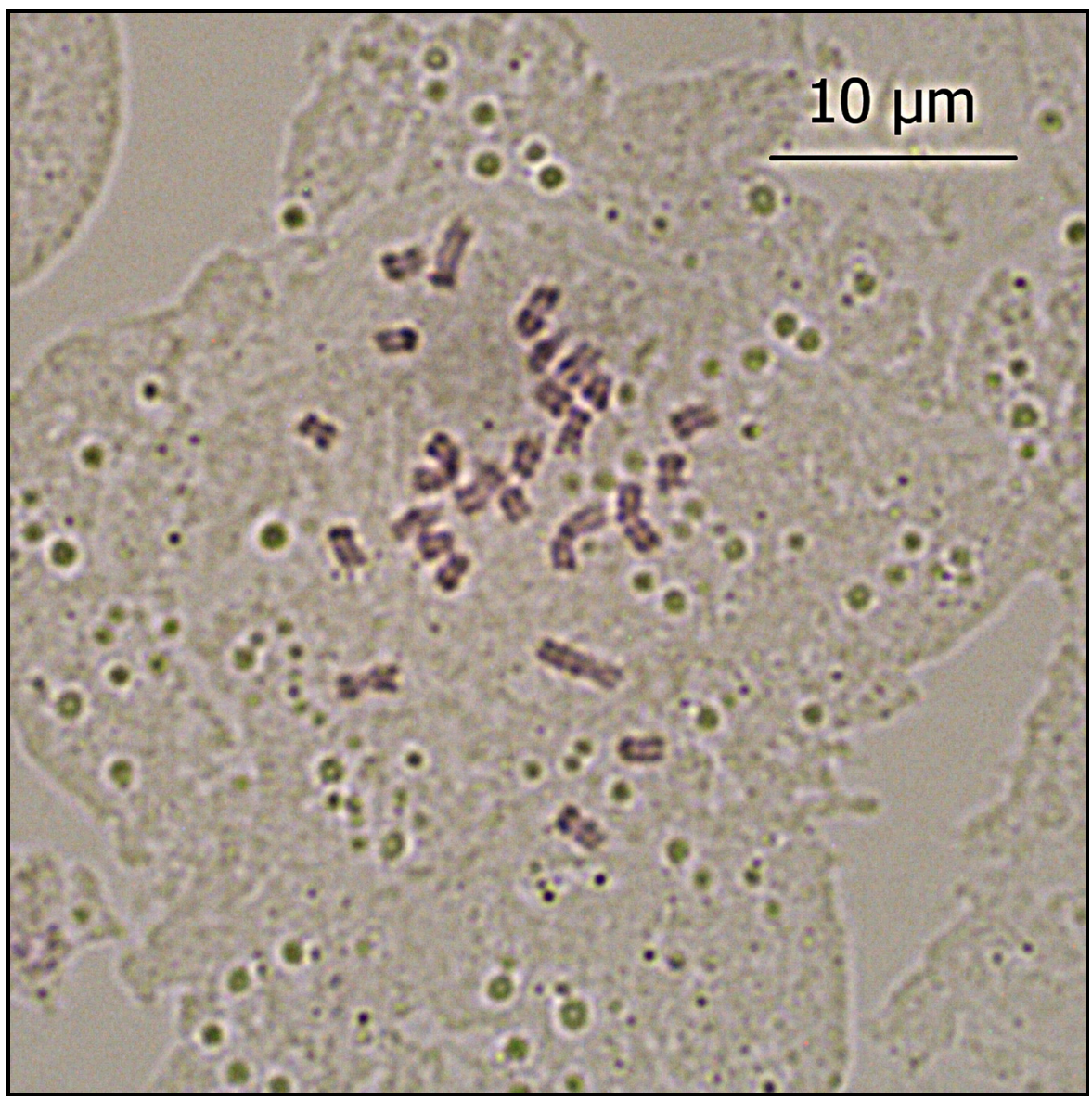

Fig. 6. - Metaphase chromosome plate of Viola orbelica Pančić $2 n=26$ (population from Mt. Dukat) (photo M. Lazarević).

\section{Estimated threatened status in Serbia}

According to the IUCN (2012) the threatened status in Serbia is critically endangered: CR B1ab(i,ii,iv)+2ab(i,ii,iv).

\section{CONCLUSIONS}

Viola orbelica represents new species for the flora of Serbia. Very restricted locality of this plant in Mt. Dukat in southeast Serbia is c. $30 \mathrm{~km}$ distant from the nearest known locality in the Republic of Macedonia (Mt. Osogovski Planini) and marks the northernmost limit of the species distribution range in the Balkan Peninsula. It is assumed that the species 
also occurs in other mountains of southeast Serbia. Using the IUCN (2012) criteria, we estimated the threatened status of this species in Serbia as Critically Endangered. We consider that $V$. orbelica should be included in the next edition of the Red Data Book of the Flora of Serbia and strictly protected by the low in the near future.

\section{Acknowledgements}

The authors would like to thank Dr. Ljiljana Tomović (Institute of Zoology, Faculty of Biology, University of Belgrade) who first noticed this plant in Mt. Dukat. The Ministry of Education, Science and Technological Development of the Republic of Serbia supported this research through Grant 173030 "Plant biodiversity of Serbia and the Balkans - assessment, sustainable use and protection".

\section{REFERENCES}

Becker, W. (1910): Violenstudien II. - Beihefte zum Botanischen Centralblatt 26(2, 3): 289-390.

Delipavlov, D. (1979): Violaceae Batsch. In: Jordanov, D. (ed.): Flora Reipublicae Popularis Bulgaricae 7: 338-395. - Bălgarskata Akademija na Naukite, Sofija. [in Bulgarian].

Dimopoulos, P., Raus, Th., Bergmeier, E., Constantinidis, Th., Iatrou, G., Kokkini, S., Strid, A., Tzanoudakis, D. (2013): Vascular plants of Greece: An annotated checklist. - Botanischer Garten und Botanisches Museum, Berlin-Dahlem; Hellenic Botanical Society, Athens.

Erben, M. (1985): Cytotaxonomische Unterschungen an Sudosteuropaischen Viola-arten der sektion Melanium. - Mitteilungen der botanischen Staatssammlung München 21: 339-740.

Euro+Med (2006-): Euro+Med PlantBase - the information resource for EuroMediterranean plant diversity. [http://ww2.bgbm.org/EuroPlusMed/] (accessed August $1^{\text {st } 2016)}$

Hayek A. (1925): Prodromus Florae Peninsulae Balcanicae 1. - Repertorium Specierum Novarum Regni Vegetabilis. Centralblatt für Sammlung und Veroffentlichung von Einzeldiagnosen neuer Pflanzen. Beihefte 30(1): 353-672.

IUCN (2012): IUCN Red List Categories and Criteria: Version 3.1. Second edition. - IUCN Species Survival Commission,. IUCN, Gland \& Cambridge.

Lampinen R. (2001): Universal Transverse Mercator (UTM) and Military Grid Reference System (MGRS). [http://www.luomus.fi/english/botany/ afe/map/ utm.htm]

Merxmüller, H. (1974): Veilchenstudien I-IV. - Phyton 16: 137-158.

Micevski, K. (1995): The Flora of the Republic of Macedonija 1(3). - Macedonian Academy of Sciences and Arts, Skopje. [in Macedonian]. 
Niketić, M. (2014): Nomenclature review of the plants published by Josif Pančić (Nomenclator Pancicianus novus). - Botanica Serbica 38(2): 209-236.

Niketić, M., Cikovac, P., Barina, Z., Pifkó, D., Melovski, Lj., Duraki, Š., Tomović, G. (2015): Viola chelmea and Viola jooi (Violaceae), new species for the flora of Serbia and their distribution in the Balkan Peninsula and the Carpathians. Bulletin of the Natural History Museum in Belgrade 8: 49-74.

Pančić J. 1883. Građa za floru kneževine Bugarske [Elementa ad floram principatus Bulgariae]. - Glasnik Srpskog učenog društva 53: 161-231. [in Serbian and Latin].

Stevanović, V., Vladimirov, V., Niketić, M., Vukojičić, S., Jakovljević, K., Lubarda, B., Tomović, G. (2014): Plant species and subspecies discovered by Dr. Josif Pančić 1 - distribution and floristic importance. - Botanica Serbica 38(2): 251-268.

The Plant List 2013. Version 1.1. [http://www.theplantlist.org/] (accessed August $1^{\text {st }}$ 2016)

Thiers, B. (2014): [continuously updated]. Index Herbariorum: A global directory of public herbaria and associated staff. New York Botanical Garden's Virtual Herbarium. [http://sweetgum.nybg.org/ih]

Tomović, G., Kuzmanović, N., Barina, Z., Đurović, S., Jakovljević, K., Vukojičić, S. (2013): Nomenclatural notes on three names in Viola Sect. Melanium (Violaceae). - Phytotaxa 123(1): 56-60.

Tomović, G., Vukojičić, S., Mirjačić, K., Radović, A., Niketić, M. (2014): Genus Viola L. (Violaceae) in Serbia-Collections of the Natural History Museum in Belgrade and the Institute of Botany and Botanical Garden "Jevremovac", Faculty of Biology, University of Belgrade. - Bulletin of the Natural History Museum in Belgrade 7: 31-91.

Tomović, G., Niketić, M., Lazarević, M., Melovski, Lj. (2016): Taxonomic reassessment of Viola aetolica and Viola elegantula ( $V$. sect. Melanium, Violaceae), with descriptions of two new species from the Balkan Peninsula. - Phytotaxa 253(4): 237-265.

Valentine, D. H., Merxmüller, H., Schmidt, A. (1968): Viola L. In: Tutin, T. G., Heywood, V. H., Burges, N. A., Moore, D. M., Valentine, D. H., Walters, S. M., Webb, D. A. (eds): Flora Europaea 2: 270-282. - University Press, Cambridge. 


\title{
VIOLA ORBELICA (VIOLACEAE), НОВA ВРСТА У ФЛОРИ СРБИЈЕ
}

\author{
ГОРДАНА ТОМОВИЋ, БОЈАН ЗЛАТКОВИЋ, МАЈА ЛАЗАРЕВИТ, \\ МАРЈАН НИКЕТИЋ
}

\section{Р Е 3 И М Е}

Током ботаничке екскурзије на подручју југоисточне Србије (Дукат планина) откривена је једна интригантна врста из рода Viola $(V$. sect. $M e$ lanium). Интензиван преглед и компарација са биљним материјалом из неколико хербарских колекција показали су да је у питању врста $V$. orbelica Pančić, која представља нову врсту за флору Србије. У раду је приказан детаљан опис, распрострањење, еколошке карактеристике, број хромозома и статус угрожености новооткривене врсте у флори Србије. 